Pengembangan LKS Berbasis PBL pada KD Menganalisis APBN dan APBD..., Volume 7 No 1 Tahun 2019

\title{
PENGEMBANGAN LKS BERBASIS PBL PADA KD MENGANALISIS APBN DAN APBD DALAM PEMBANGUNAN EKONOMI DI SMA NEGERI 1 AROSBAYA BANGKALAN
}

\author{
Muchammad Noor Iksan
}

S1 Pendidikan Ekonomi, Fakultas Ekonomi, Universitas Negeri Surabaya, muchammadiksan@mhs.unesa.ac.id

\begin{abstract}
Abstrak
Lembar Kegiatan Siswa (LKS) merupakan lembaran-lembaran berisi tugas yang harus dikerjakan oleh siswa. LKS berbasis PBL dipilih untuk menjawab tuntutan kurikulum 2013 yang mengharuskan siswa berperan aktif dalam proses pembelajaran. Tujuan dari penelitian ini adalah untuk menganalisis proses pengembangan LKS berbasis model pembelajaran problem based learning (PBL) pada kompetensi dasar APBN dan APBD dalam pembangunan ekonomi, menganalisis kelayakan LKS berbasis model pembelajaran problem based learning (PBL) pada kompetensi dasar APBN dan APBD dalam pembangunan ekonomi, serta menganalisis respon siswa kelas XI SMA Negeri 1 Arosbaya Bangkalan terhadap pengembangan LKS berbasis model pembelajaran problem based learning (PBL) pada kompetensi dasar APBN dan APBD dalam pembangunan ekonomi. Dari penelitian ini dierpoleh hasil pengembangan LKS berbasis model pembelajaran problem based learning (PBL) pada kompetensi dasar APBN dan APBD dalam pembangunan ekonomi memiliki rata-rata presentase sebesar 84,34\%, yang termasuk kedalam kategori sangat layak, dan respon siswa mendapat hasil rata-rata sebesar 94,58\% dengan kategori sangat layak. Dengan demikian, LKS berbasis model pembelajaran PBL sangat layak untuk diterapkan didalam proses pembelajaran.
\end{abstract}

Kata Kunci: Pengembangan, LKS, Problem Based Learning.

\begin{abstract}
Student worksheet containing the tasks that must be done by the students. Student worksheet based on Problem Based Learning (PBL) was chosen to fulfill the demands of the 2013 curriculum that requires students to give an active role in the learning process. This research aims to analyze the process of developing and to analyze the feasibility of student worksheet based on problem based learning model $(P B L)$ on basic competence of $A P B N$ and $A P B D$ in economic development, and analyzing the responses of students of grade XI SMA Negeri 1 Arosbaya Bangkalan to the development of student worksheet based on problem based learning (PBL) learning model on basic competence of APBN and APBD in economic development. The results of this research are development of student worksheet based on problem based learning (PBL) model on basic competence of $A P B N$ and APBD in economic development have average percentage equal to $84,34 \%$, with very eligible category, student response obtained average result equal to 94,58\% with very decent category. Thus, the student worksheet based on Problem Based Learning (PBL) model is very feasible to be used as additional teaching materials.
\end{abstract}

Keywords: Development, Student Worksheet, Problem Based Learning.

\section{PENDAHULUAN}

Lembar Kegiatan Siswa (LKS) merupakan sebuah produk penunjang proses pembelajaran yang berfokus pada siswa serta disusun berdasarkan materi pembelajaran (Amri, 2013). LKS memiliki beberapa fungsi yang salah satunya mampu meminimalkan peran guru dan juga mampu meningkatkan keaktifan siswa. Dalam kurikulum 2013 siswa dituntut untuk berperan aktif didalam proses pembelajaran, sehingga Lembar Kegiatan Siswa (LKS) sangat sesuai untuk diterapkan sebagai bahan ajar.

LKS berbasis Problem Based Learning (PBL) dipilih untuk menjawab tuntutan kurikulum 2013 yang mengharuskan siswa berperan aktif dalam kegiatan pembelajaran. LKS yang ada pada buku paket yang digunakan oleh sekolah memuat sebagian besar materi di dalam buku tersebut, sehingga kemandirian siswa dalam mencari informasi menjadi kurang maksimal.

Salah satu materi yang substansinya cenderung berubah mengikuti Undang-undang yang berlaku adalah materi APBN dan APBD pada Kompetensi Dasar (KD) Menganalisis APBN dan APBD dalam pembangunan ekonomi. Materi ini banyak membuat siswa kesulitan dikarenakan banyaknya komponen-komponen yang terdapat dalam APBN dan APBD, serta komponennya yang cenderung berubah mengikuti Undang-undang yang berlaku sedangkan buku teks yang digunakan oleh sekolah cenderung terlambat mengikuti perkembangan. Sehingga sehingga dalam proses pembelajaran guru perlu menyusun Lembar Kegiatan Siswa (LKS) sebagai sumber pendamping. 
Dari hasil wawancara yang dilakukan tanggal 4 Januari 2017 di SMA Negeri 1 Arosbaya, didapati bahwa dalam proses pembelajaran, guru sudah mengaplikasikan model pembelajaran Problem Based Learning (PBL) namun hanya sebatas diskusi untuk memecahkan masalah yang termuat dalam buku paket.

Dalam Mulyani (2013) Contoh LKS pada buku paket yang digunakan oleh sekolah adalah sebagai berikut.

"Carilah data pokok APBN Indonesia melalui internet! Analisislah pos-pos pengeluaran pemerintah selama 5 tahun terakhir! Identifikasikan pos pengeluaran pemerintah dari yang terbesar hingga yang terkecil! Coba buatlah analisis dan simpulan sederhana mengenai pengaruh belanja pemerintah terhadap kesejahteraan masyarakat! Misalnya, pengeluaran subsidi BBM dapat mengendalikan harga-harga sehingga dapat terjangkau oleh masyarakat. Buatlah laporan secukupnya dan presentasikan didepan kelas! Adapun guru dan siswa lain dapat memberikan tanggapan".

LKS tersebut dirasa kurang mampu untuk meningkatkan kemandirian siswa dalam mencari informasi, dikarenakan sebagian besar materi sudah termuat di dalam buku tersebut. LKS berbasis Problem Based Learning (PBL) memiliki ciri-ciri salah satunya adalah membimbing siswa untuk berpikir kritis dengan menyediakan sumber daya yang terbatas, sehingga LKS yang ada dirasa kurang memenuhi ciri-ciri tersebut. Untuk LKS yang dikembangkan oleh pendidik belum pernah dilakukan pengembangan, sehingga dirasa perlu untuk mengembangkan Lembar Kegiatan Siswa (LKS) guna menunjang pembelajaran yang sesuai dengan Problem Based Learning (PBL).

Penelitian ini relevan dengan penelitian terdahulu yang dilakukan oleh Nurhayati dkk (2015) dengan judul "Pengembangan LKS Berbasis Problem Based Learning (PBL) Pokok Bahasan Tahap Pencatatan Akuntansi Perusahaan Jasa" menyatakan bahwa, LKS berbasis PBL yang dikembangkan memiliki kualitas sangat baik. Namun, LKS yang dikembangkan masih beracuan pada kurukulum KTSP. Oleh sebab itu, peneliti ingin meneliti apakah LKS berbasis PBL juga memberikan hasil yang positif jika beracuan pada Kurikilum 2013.

Penelitian ini bertujuan untuk 1) Menganalisis proses pengembangan LKS berbasis model pembelajaran problem based learning (PBL) pada kompetensi dasar APBN dan APBD dalam pembangunan ekonomi di SMA Negeri 1 Arosbaya Bangkalan, 2) Menganalisis kelayakan LKS berbasis model pembelajaran problem based learning (PBL) pada kompetensi dasar APBN dan APBD dalam pembangunan ekonomi di SMA Negeri 1 Arosbaya Bangkalan. 3) Menganalisis respon siswa terhadap pengembangan LKS berbasis model pembelajaran problem based learning (PBL) pada kompetensi dasar APBN dan APBD dalam pembangunan ekonomi di SMA Negeri 1 Arosbaya Bangkalan.

Lembar Kegiatan Siswa (student worksheet) merupakan lembaran-lembaran yang harus dikerjakan oleh siswa yang berisi tugas-tugas (Depdiknas, 2008). Sedangkan menurut Prastowo (2015) Lembar Kegiatan Siswa adalah suatu bahan ajar yang berbentuk lembaran kertas yang memuat ringkasan materi, serta petunjuk pengerjaan tugas yang harus dikerjakan oleh siswa, yang beracuan pada KD yang hendak dikuasai. Dengan demikian, dapat didefinisikan bahwa Lembar Kegiatan Siswa (LKS) merupakan seperangkat alat pembelajaran berupa lembaran-lembaran yang berisikan materi pembelajaran, tugas-tugas, serta petunjuk pengerjaannya yang disusun secara sistematis untuk diaplikasikan dalam pembelajaran sesuai dengan tujuan yang disepakati.

Pada umumnya bentuk LKS yang digunakan oleh peserta didik ada lima. Sebagaimana pendapat Prastowo (2015) lima macam bentuk tersebut, yaitu LKS yang membantu siswa menemukan suatu konsep, LKS yang membantu siswa menerapkan dan mengintegrasikan berbagai konsep yang telah ditemukan, LKS yang berfungsi sebagai petunjuk praktikum, LKS yang berfungsi sebagai penuntun belajar, serta LKS yang berfungsi sebagai penguatan.

Pada penelitian ini, jenis LKS yang disusun yaitu LKS yang membantu siswa menghafal dan memahami materi yang disajikan. Disamping itu, LKS berfokus pada penggunaan masalah guna mengembangkan keterampilan berpikir, dan mengembangkan kemandirian peserta didik melalui analisis data APBD.

Menurut Depdiknas (2008) langkah-langkah yang harus dilakukan dalam meyusun LKS yang pertama adalah melakukan analisis kurikulum, dimana maksud dari kegiatan ini adalah untuk menentukan materi mana saja yang diperlukan adanya LKS. Yang kedua yaitu menyusun peta kebutuhan LKS, dengan tujuan agar diketahui jumlah LKS yang akan ditulis dan urutannya juga bisa diketahui. Selanjutnya adalah menetukan juduljudul LKS, penentuan judul LKS didasarkan pada KD$\mathrm{KD}$, materi-materi utama atau pengalaman belajar yang ada pada kurikulum. Kemudian yang terakhir adalah penulisan LKS yang ditempuh dengan cara merumuskan KD yang harus dikuasai, menentukan alat penilaian, menyusun materi, dan membuat struktur LKS.

Menurut Arends (dalam Warsono \& Hariyanto, 2012) PBL didefinisikan sebagai sebuah model pembelajaran yang membentuk dan melibatkan siswa dalam belajar dan dalam proses mencari solusi. Sedangkan menurut Yazdani (dalam Nur, 2008) berpendapat bahwa PBL adalah model pembelajaran yang berdasar pada penggunaan masalah-masalah sebagai 
awal untuk memperoleh pengetahuan baru. Berdasarkan dari definisi-definisi PBL yang telah di kemukakan, dapat ditarik kesimpulan bahwa PBL adalah suatu model pembelajaran yang berfokus pada penggunaan masalah guna meningkatkan keterampilan berpikir, dan mengembangkan kemandirian peserta didik.

Menurut Undang-undang Nomor 18 tentang Anggaran Pendapatan dan Belanja Negara (2016), "Anggaran Pendapatan dan Belanja Negara (APBN) adalah rencana keuangan tahunan pemerintahan negara yang disetujui oleh DPR". Menurut Mulyani (2013) Anggaran Pendapatan dan Belanja Daerah (APBD) merupakan suatu daftar yang memuat sumber-sumber penerimaan daerah dan alokasi pengeluaran daerah dalam satu periode.

Diharapkan hasil dari penelitian yang dilakukan dapat menambah variasi bahan belajar terutama pada kompetensi dasar APBN dan APBD dalam pembangunan ekonomi serta mampu memudahkan siswa untuk meningkatkan pemahaman terhadap materi yang disampaikan.

\section{METODE}

Jenis penelitian dari penelitian ini adalah research and development $(\mathrm{RnD})$ dengan menggunakan model 4D dari Thiagarajan yang terdiri dari empat tahap yaitu Tahap Pendefinisian (Define), Tahap Perancangan (Design), Tahap Pengembangan (Develop), Tahap Penyebaran (Disseminate) (dalam Trianto, 2013). Namun karena keterbatasan penulis, tahap penyebaran (Disseminate) tidak dilaksanakan.

Kriteria kelayakan LKS terdiri dari kelayakan isi, penyajian, kebahasaan, serta kelayakan kegrafikan. Penilaian buku teks yang diadaptasi dari Badan Standar Nasional Pendidikan dijadikan acuan dalam menentukan kriteria kelayakan LKS (BSNP, 2014).

Produk yang dihasilkan dari penelitian ini ialah LKS berbasis PBL pada kompetensi dasar APBN dan APBD dalam pembangunan ekonomi. Subjek dalam penelitian ini adalah Ahli materi, ahli pembelajaran, ahli bahasa, ahli grafis, serta siswa kelas XI SMAN 1 Arosbaya sejumlah 20 orang peserta didik sebagai sample.

Uji coba produk menggunakan model one-shot case study yaitu dengan memberikan perlakuan berupa proses pembelajaran menggunakan LKS berbasis PBL pada materi APBN dan APBD kelas XI. Kemudian dianalisis respon siswa terhadap LKS yang telah disajikan.

Penelitian ini menggunakan instrumen pengumpulan data berupa lembar angket terbuka dan angket tertutup. Data hasil telaah para ahli digunakan untuk memperbaiki komponen-komponen yang terdapat di dalam LKS. Untuk data hasil validasi dianalisis secara desktriptif kuantitatif yaitu dengan memberikan deskripsi mengenai LKS dengan menggunakan nilai peringkat berdasarkan skala Linkert. Sedangkan untuk angket respon siswa diukur menggunakan skala Guttman.

Teknik analisis data menggunakan analisis kelayakan LKS, dan angket respon siswa berdasarkan skala Linkert. LKS dikatakan layak jika mencapai $\geq 61 \%$. Respon siswa terhadap LKS dikatakan positif jika persentase keseluruhan aspek $\geq 61 \%$.

\section{HASIL DAN PEMBAHASAN}

Pengembangan LKS berbasis model pembelajaran problem based learning (PBL)

Pengembangan LKS berbasis model pembelajaran Problem Based Learning (PBL) ini mengacu pada model pengembangan Thiagarajan (dalam Trianto, 2013). Model ini terdiri atas tahap define (pendefinisian), design (perancangan), develop (pengembangan). Tahapan tersebut dijabarkan sebagai berikut.

1. Tahap pendefinisian (define)

Thiagarajan dalam Trianto (2013) menyatakan bahwa tahap define terdiri atas analisis awal, analisis siswa, analisis konsep, analisis tugas, dan analisis tujuan pembelajaran.

Analisis awal dilakukan dengan memperhatikan kurikulum yang diterapkan oleh sekolah. Kurikulum yang dipakai di SMAN 1 Arosbaya adalah kurikulum 2013. Salah satu materi yang terdapat dalam silabus ekonomi kelas XI adalah APBN dan APBD. Ada dua kompetensi dasar dari materi ini yaitu, menganalisis APBN dan APBD dalam pembangunan ekonomi serta menyajikan hasil analisis APBN dan APBD dalam pembangunan ekonomi.

Indikator-indikator dalam pembelajaran diperoleh dengan merinci $\mathrm{KI}$ dan $\mathrm{KD}$ yang ada pada silabus ekonomi kelas XI.

Analisis siswa ditemukan bahwa siswa kelas XI MIPA 2 memiliki kemampuan dan pengetahuan yang heterogen dalam pemahaman dan penguasaan materi. Ada beberapa siswa yang memliki tingkat pemahaman dan penguasaan materi lebih baik dibandingkan teman-temannya, ada sebagian siswa yang memiliki tingkat pemahaman dan penguasaan materi pada tingkat rata-rata, serta ada pula beberapa siswa yang memiliki tingkat pemahaman dan penguasaan materi rendah.

Pembelajaran menggunakan LKS memungkinkan siswa berkemampuan lebih dibandingkan siswa yang lain akan lebih cepat dalam mempelajari kompetensi dasar yang disampaikan, sehingga mereka lebih semangat dalam proses belajar. 
Dengan adanya LKS, siswa juga berkesempatan untuk belajar secara mandiri dan mengurangi ketergantungan siswa terhadap kehadiran guru (Amri dan Lif, 2010). Berdasarkan hal tersebut, LKS dirasa sesuai untuk diterapkan sebagai bahan ajar.

Analisis konsep diperlukan agar konsepkonsep yang sesuai dengan KD dapat ditemukan. Analisis konsep dilakukan dengan merinci kompetensi dasar yang dipilih kemudian menyusun indikatorindikator sesuai dengan kompetensi dasar tersebut. Konsep yang dipilih disesuaikan dengan indikator dari kompetensi dasar yang dipilih.

Analisis tugas dilakukan melalui penentuan butir-butir soal atau latihan sesuai dengan indikator yang telah disusun. LKS yang dikembangkan ini memuat dua jenis tugas yaitu, tugas kelompok dan individu. Tugas kelompok atau diskusi terdapat pada LKS 2 dan LKS 4, sedangkan tugas individu terdapat pada LKS 1, LKS 3, serta pelatihan diakhir pembelajaran.

Analisis tujuan pembelajaran disusun dari hasil mengonversikan analisis konsep dan analisis tugas menjadi tujuan pembelajaran.

2. Tahap perancangan (design)

Tahap design ini terdiri atas tahap pemilihan format dan desain LKS.

Pemilihan format pada LKS berbasis PBL ini adalah berupa pendahuluan, isi, dan penutup berupa latihan-latihan soal. LKS ini menyesuaikan dengan sintaks PBL yang terdiri atas lima fase sebagaimana disebutkan pada Bab II.

LKS yang dikembangkan menggunakan format A4 untuk ukuran kertas seusuai dengan standard BSNP, dan dipilih font book antiqua ukuran 12 . Format ini selanjutnya akan menghasilkan draft awal atau draft I.

Desain LKS merupakan suatu kegiatan merancang LKS yang bertujuan untuk menarik dan meningkatkan minat siswa untuk belajar sesuai dengan sintaks PBL dengan bimbingan guru maupun tanpa bimbingan guru.

Kegiatan dari desain LKS ini merupakan tindak lanjut dari pemilihan format yang sudah dilakukan sebelumya yang kemudian akan dikembangkan lebih lanjut pada tahap develop (pengembangan).

3. Tahap pengembangan (develop)

Tahap ini terdiri atas proses telaah oleh ahliahli yang ditunjuk, perbaikan, draf II, validasi, serta uji coba terbatas pada siswa kelas XI MIPA 2 SMAN 1 Arosbaya. Hasil dari tahapan ini adalah LKS utuh yang telah dinyatakan layak untuk digunakan dalam pembelajaran.

\section{Kelayakan LKS berbasis model pembelajaran} problem based learning (PBL)

Sebuah LKS boleh dikatakan layak jika hasil dari validasi Lembar Kegitan Siswa (LKS) mencapai persentase $\geq 61 \%$ (Riduwan, 2013).

Kelayakan LKS didapat dari hasil validasi yang dilakukan oleh validator sesuai dengan kriteria Badan Standard Nasional Pendidikan (BSNP) tahun 2014, serta kesesuaian LKS dengan model pembelajaran yang dipilih. Validator LKS terdiri dari lima orang yang masing-masing merupakan guru mata pelajaran ekonomi dan dosen ekonomi sebagai ahli materi, dosen ekonomi sebagai ahli pembelajaran, dosen bahasa Indonesia sebagai ahli bahasa, serta dosen teknologi pendidikan sebagai ahli grafis.

Hasil analisis validasi ahli materi diperoleh presentase $86,83 \%$, dengan kategori sangat layak. Hasil tersebut meliputi aspek cakupan materi,keakuratan materi, kemutakhiran dan kekontekstualan, dimensi keteramplan (KI4), teknik penyajian, pendukung penyajian materi, penyajian pembelajaran, dan kelengkapan penyajian.

Hasil analisis validasi ahli pembelajaran diperoleh presentase $80 \%$, dengan kategori layak. Hasil tersebut meliputi aspek-aspek sesuai dengan sintaks model pembelajaran PBL.

Hasil analisis validasi ahli bahasa diperoleh presentase 94,28\%, dengan kategori sangat layak. Hasil tersebut meliputi aspek-aspek kebahasaan sesuai dengan kriteria BSNP.

Hasil analisis validasi ahli grafis diperoleh presentase $76,67 \%$, dengan kategori layak. Hasil tersebut meliputi aspek ukuran LKS, desain kulit LKS, dan desain isi LKS.

Keseluruhasn analisis hasil validasi ahli diatas memperoleh presentase rata-rata sebesar $84,45 \%$, yang termasuk dalam kategori sangat layak. Dari hasil tersebut dapat ditarik kesimpulan bahwa LKS berbasis model PBL ini dapat diterapkan sebagai bahan ajar dalam proses pembelajaran.

\section{Respon siswa terhadap pengembangan LKS berbasis} model pembelajaran problem based learning (PBL)

Uji coba produk diterapkan pada dua puluh siswa kelas XI MIPA 2 SMA Negeri 1 Arosbaya. Tujuan dari kegiatan ini adalah agar diketahui bagaimana tanggapan siswa mengenai LKS yang dikembangkan.

Respons siswa dari komponen isi atau materi LKS mendapatkan presentase $96,25 \%$ dengan kriteria sangat layak. Hasil tersebut sesuai dengan angket respons siswa yang menegaskan bahwa materi yang disajikan mudah dipahami, materi yang disajikan terakait dengan kehidupan nyata, materi yang disajikan mampu 
menambah wawasan, serta materi yang disajikan mulai dari yang mudah sampai yang sulit.

Komponen penyajian mendapatkan presentase $90 \%$, yang termasuk kategori sangat layak. Hasil tersebut berdasarkan pada angket respons siswa yang menegaskan bahwa LKS tampilannya menarik, siswa termotivasi untuk belajar dengan adanya LKS ini, ringkasan materi membuat siswa memahami isi materi dengan lebih cepat dan jelas, serta materi yang disajikan sesuai dengan PBL.

Komponen kebahasaan diperoleh presentase $98,75 \%$, yang termasuk kategori sangat layak. Hal ini sesuai dengan angket respons siswa yang mengungkapkan bahwa bahasa yang digunakan mudah untuk dipahami, materi yang dimuat memakai kalimat yang jelas, istilah yang digunakan mudah dipahami, serta bahasa yang digunakan komunikatif dan interaktif.

Komponen kegrafikan diperoleh presentase 93,33\%, masuk dalam kategori sangat layak. Data tersebut berdasarkan pada angket respons siswa yang mengungkapkan bahwa warna cover menarik, jenis huruf yang digunakan jelas, serta ilustrasi yang ditampilkan memudahkan saya dalam memahami materi.

Keseluruhan hasil analisis respon siswa berdasarkan komponen diatas didapat rerata presentase 94,58\%, yang menurut Riduwan (2013) termasuk kategori sangat layak. Hal ini juga relevan dengan penelitian yang telah dilakukan oleh Nurhayati, dkk (2015) dimana dalam penelitian tersebut LKS yang dikembangkan oleh peneliti memiliki kualitas yang sangat baik. Sehingga, dapat disimpulkan bahwa LKS berbasis PBL sangat layak untuk diaplikasikan dalam pembelajaran.

\section{PENUTUP}

Simpulan

Setelah melakukan pengembangan dan pembahasan, maka kesimpulan yang diperoleh adalah pengembangan LKS berbasis problem based learning pada kompetensi dasar menganalisis APBN dan APBD dalam pembangunan ekonomi ini dipilih model 4-D dari Thiagarajan, Semmel dan Semmel yang pada penelitian ini diterapkan tahap define (pendefinisian), design (perancangan), develop (pengembangan). Telaah dan validasi dilakukan oleh empat ahli yaitu, ahli materi, ahli pembelajaran, ahli bahasa, dan ahli grafis.

Hasil kelayakan LKS sebagai bahan ajar diperoleh kriteria sangat layak untuk diterapkan sebagai bahan ajar dalam kegiatan pembelajaran ekonomi pada kompetensi dasar menganalisis APBN dan APBD dalam pembangunan ekonomi. Hal ini berdasar dari hasil validasi yang dilakukan oleh para validator yang telah ditunjuk.

Pada uji coba terbatas, respon siswa terhadap LKS berbasis problem based learning pada kompetensi dasar menganalisis APBN dan APBD dalam pembangunan ekonomi diperoleh kriteria sangat layak. Berdasarkan hasil tersebut, LKS berbasis problem based learning pada kompetensi dasar menganalisis APBN dan APBD dalam pembangunan ekonomi yang dikembangkan dapat diterapkan sebagai bahan ajar penunjang pembelajaran ekonomi kompetensi dasar menganalisis APBN dan APBD dalam pembangunan ekonomi.

\section{Saran}

Sub materi yang diambil hanya meliputi pengertian APBN dan APBD, sumber-sumber pendapatan dan pengeluaran negara dan daerah, pengaruh APBN dan APBD terhadap perekonomian, yang terdapat pada kompetensi dasar menganalisis APBN dan APBD dalam pembangunan ekonomi. Sehingga, diperlukan pengembngan LKS lebih lanjut dengan sub materi lain dari kompetensi dasar menganalisis APBN dan APBD dalam pembangunan ekonomi.

\section{DAFTAR PUSTAKA}

Amri, Sofan. 2013. Pengembangan dan Model Pembelajaran dalam Kurikulum 2013. Jakarta: Prestasi Pustaka

Amri, Sofan dan Lif Khoiru Ahmadi. 2010. Konstruksi Pengembangan Pembelajaran. Jakarta: Prestasi Pustaka

BSNP. 2014. Instrumen Penilaian Buku Teks Peajaran Tahun 2014. Jakarta: Badan Standar Nasional Pendidikan, (Online), ( indonesia.org/2014/05/28/instrumen-penilaian-bukuteks-pelajaran-tahun-2014/04-EKONOMI, diakses 16 Maret 2017)

Departemen Pendidikan Nasional. 2008. Panduan Pengembangan Bahan Ajar. Depdiknas: Jakarta

Mulyani, Endang. 2015. Ekonomi 2 Untuk Kelas XI SMA dan MA Kelompok Peminatan Ilmu-ilmu Sosial. Surakarta: Tiga Serangkai Pustaka Mandiri

Nur, Mohamad. 2008. Model Pembelajaran Berdasarkan Masalah. Surabaya: Pusat SAINS Dan Matematika Sekolah Unesa

Nurhayati, Fitri, Joko Widodo, Etty Soesilowati. 2015. "Pengembangan LKS Berbasis Problem Based Learning (PBL) Pokok Bahasan Tahap Pencatatan Akuntansi Perusahaan Jasa". Journal of Economics Education. Vol. 4 (1): hal 14.

Prastowo, Andi. 2015. Panduan Kreatif Membuat Bahan Ajar Inovatif Menciptakan Metode Pembelajaran yang Menarik dan Menyenangkan. Yogyakarta: Diva Press

Riduwan. 2013. Dasar-dasar Statistika. Bandung: Alfabeta 
Trianto. 2013. Mendesain Model Pembeajaran Inovatif, Progresif dan Kontekstual: Konsep, Landasan, dan Implementasinya pada Kurikulum 2013 (Kurikulum Tematik Integratif/KTI). Jakarta: Prenadamedia Group

Undang-undang Republik Indonesia No. 18 Tahun 2016 tentang Anggaran Pendapatan dan Belanja Negara

Warsono \& Hariyanto. 2012. Pembelajaran Aktif. Bandung: Remaja Rosdakarya

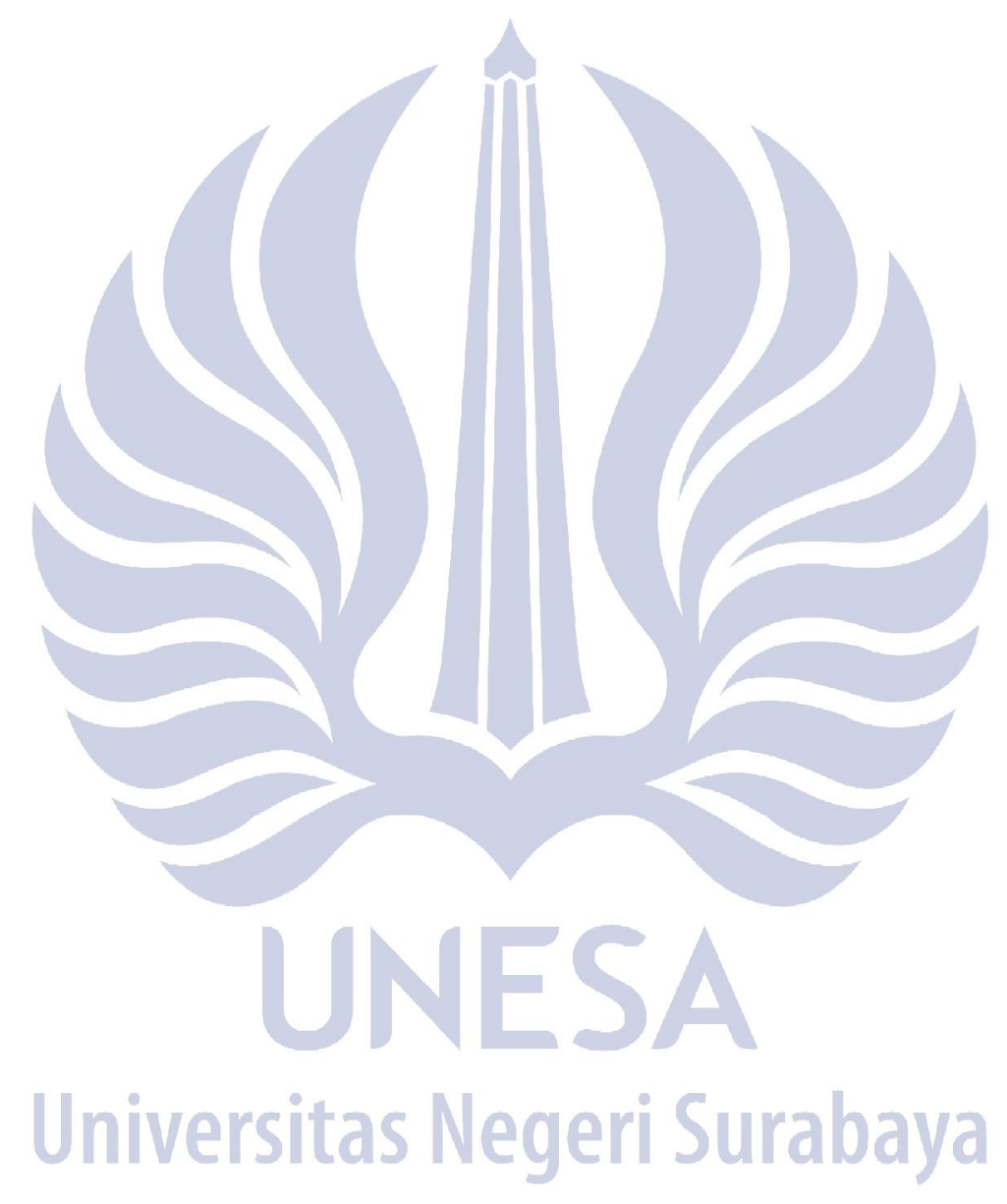

